Critical remarks on the ADR Directive

Peer-reviewed author version

CAUFFMAN, Caroline (2016) Critical remarks on the ADR Directive. In: Cauffman, Caroline; Smits, Jan (Ed.). The Citizen in European private law: norm-setting, enforcement and choice, Intersentia, p. 155-160.

DOI: $10.2139 /$ ssrn.2885509

Handle: http://hdl.handle.net/1942/26101 


\title{
CRITICAL REMARKS ON THE ADR DIRECTIVE
}

\author{
Caroline Cauffman \\ Maastricht University \\ caroline.cauffman@maastrichtuniversity.nl
}

\begin{abstract}
The ADR Directive pursues an honourable aim trying to provide consumers and traders with access to a simple, fast and low-cost method of dispute resolution. In the short term, it will probably improve the position of consumers compared to the status quo ante. However, it does not guarantee consumers the remedy they are entitled to. It institutionalises a system that does not meet the standards for the proper administration of justice and it may jeopardise the efforts made for the harmonization of the material rules of consumer protection and the creation of a level playing field for traders in the internal market in the long term. An EU measure aimed at amending the existing court procedures in the Member States in order to make them better suited to deal with low value consumer claims would have been preferable.
\end{abstract}

Keywords: consumer law, ADR, ADR Directive 


\title{
CRITICAL REMARKS ON THE ADR DIRECTIVE
}

\author{
Caroline Cauffman
}

\section{Introduction: the aims of the ADR Directive}

The Alternative Dispute Resolution Directive (the ADR Directive) ${ }^{1}$ aims to increase the consumer's access to justice. This is of course an honourable aim. The EU has a vast track record of creating directives which oblige Member States to offer a certain minimum level of consumer protection. ${ }^{2}$ Recently, it has moved to adopt consumer directives that introduce full harmonization ${ }^{3}$ as well as directly applicable regulations ${ }^{4}$. This should ensure an identical level of consumer protection for consumers throughout the EU. When the mechanisms available to enforce these rights are not available to consumers because of high cost or complicated procedures, these consumers' rights however remain highly theoretical. In the past, the EU already tried to overcome this problem through the Injunctions Directive ${ }^{5}$ under which Member States need to appoint institutions or organisations capable of bringing actions aimed at the cessation of illegal conduct towards consumers. However, these cessation actions only have a preventative aim: preventing future

\footnotetext{
${ }^{1}$ Directive 2013/11/EU of 21 May 2013 on alternative dispute resolution for consumer disputes and amending Regulation (EC) No 2006/2004 and Directive 2009/22/EC, OJ L 165/63, 18 June 2013. The ADR Directive is accompanied by the ODR Regulation (Regulation 524/2013 of 21 May 2013 on online dispute resolution for consumer disputes and amending Regulation (EC) No 2006/2004 and Directive 2009/22/EC, OJ L 165/1, 18 June 2013). The latter provides for the establishment of an ODR platform which offers consumers and traders a single point of entry for the out-of-court resolution of online disputes, through ADR entities which are linked to the platform. See Recital 12 of the ADR Directive.

2 See e.g. Council Directive 85/577/EEC of 20 December 1985 to protect the consumer in respect of contracts negotiated away from business premises, OJ L 372, 31/12/1985, p. 0031 - 0033; Council Directive 93/13/EEC of 5 April 1993 on unfair terms in consumer contracts, Official Journal L 095 , 21/04/1993, p. 0029 - 0034; Directive 97/7/EC of the European Parliament and of the Council of 20 May 1997 on the protection of consumers in respect of distance contracts, OJ L 144, 4.6.1997, p. 19-27.

3 See e.g. Directive 2011/83/EU of the European Parliament and of the Council of 25 October 2011 on consumer rights, amending Council Directive 93/13/EEC and Directive 1999/44/EC of the European Parliament and of the Council and repealing Council Directive 85/577/EEC and Directive 97/7/EC of the European Parliament and of the Council, OJ L 304, 22.11.2011, p. 64-88; Directive 2005/29/EC of the European Parliament and of the Council of 11 May 2005 concerning unfair business-to-consumer commercial practices in the internal market and amending Council Directive 84/450/EEC, Directives 97/7/EC, 98/27/EC and 2002/65/EC of the European Parliament and of the Council and Regulation (EC) No 2006/2004 of the European Parliament and of the Council ('Unfair Commercial Practices Directive'), OJ L 149, 11.6.2005, p. 22-39.

${ }^{4}$ See the ODR Regulation mentioned in the previous footnote.

${ }^{5}$ Directive 98/27/EC of the European Parliament and of the Council of 19 May 1998 on injunctions for the protection of consumers' interests, OJ L 166, 11 June 1998.
} 
illegal conduct towards consumers. They provide no solution for the ex post resolution of disputes between an individual seller and an individual consumer.

In this context, the ADR Directive aims to provide individuals and traders with access to a simple, fast and low-cost method of dispute resolution. This should result in a high level of consumer protection boosting consumers' confidence in the internal market and should contribute to the proper functioning thereof. ${ }^{6}$ Whether it will reach these aims remains to be seen. Some of the weaknesses of the ADR Directive will be discussed below ${ }^{7}$.

\section{The Weaknesses of the ADR Directive}

A first weakness of the ADR Directive is that it leaves it to the Member States to determine whether the participation of traders in ADR procedures is mandatory ${ }^{8}$. This has the potential to undermine the envisaged level playing field for traders and is not conducive for consumer confidence in cross-border trade, which may ultimately be harmful for the internal market, contrary to the aims of the Directive ${ }^{9}$.

Secondly, the ADR Directive allows Member States to choose between ADR entities which propose or impose a solution or bring parties together with the aim of facilitating an amicable solution or a combination of these mechanisms ${ }^{10}$. This too may lead to an uneven level playing field within the internal market. This effect is reinforced by the combination of this freedom of choice with the Directive's rules on

\footnotetext{
${ }^{6}$ Art. 1 juncto Recitals 4 and 5 of the ADR Directive.

${ }^{7}$ For a critical view on the ADR Directive, see also H. Eidenmüller, \& M. Engel, "Die Schlichtungsfalle: Verbraucherrechtsdurchsetzung nach der ADR-Richtlinie und der ODR-Verordnung der EU", Zeitschrift für Wirtschaftsrecht, 2013, 1704-1710; H. Eidenmüller \& M. Engel, "Against False Settlement: Designing Efficient Consumer Rights Enforcement Systems in Europe", Ohio State Journal on Dispute Resolution, 29, 2014, 261-296; C. Meller-Hannich, A. Höland \& E. Krausbeck, " "ADR" und "ODR": Kreationen der europäischen Rechtspolitik. Eine kritische Würdigung", Zeitschrift für Europäisches Privatrecht, 2014, 8-38; G. Rühl, "Alternative and Online Dispute Resolution for (CrossBorder) Consumer Contracts: A Critical Evaluation of the European Legislature's Recent Efforts to promote Competitiveness and Growth in the Internal Market", 38 Journal of Consumer Policy 2015, in print and http://ssrn.com/abstract=2632117; G. Wagner, "Private Law Enforcement through ADR: Wonder Drug or Snake Oil", CMLR 2014, 165-194; F. Weber, "Is ADR the Superior Mechanism for Consumer Contractual Disputes? - an Assessment of the Incentivizing Effects of the ADR Directive", 38 Journal of Consumer Policy 2015, 265-285.

8 Recital 49 of the ADR Directive.

${ }^{9}$ Cf. supra.

${ }^{10}$ Recital 21 ADR Directive.
} 
the extent to which an ADR outcome needs to comply with the applicable rules of material consumer law.

Where ADR bodies impose solutions, they are bound by the principle of legality. This means that their solutions may not deprive the consumer of the protection he is entitled to by the mandatory provisions of the law of the Member State where he is habitually resident ${ }^{11}$. However, since the ADR bodies are not courts, they may not make preliminary referrals to the Court of Justice in case they are uncertain about the interpretation of rules of consumer law based on EU law ${ }^{12}$.

However, where an ADR body merely proposes a solution, this solution may be less beneficial to the consumer compared to what he would obtain as a result of a court procedure ${ }^{13}$. It seems that it may even be less beneficial than the minimum he is entitled to under the material rules of EU consumer law. Equally, where the ADR body only brings parties together with the aim of facilitating an amicable solution there is nothing that prevents a solution that is less beneficial than the solution the consumer is legally entitled to. It is true that the consumer may refuse to accept the solution proposed by either the ADR body or the trader and bring court proceedings. ${ }^{14}$ Article 9(2)(b)(ii) ADR Directive even seems to leave open the possibility for the consumer to accept the proposal and afterwards seek redress through court proceedings, without specifying the impact of this on the accepted proposal and vice versa. In any case, the whole idea of ADR is to provide the consumer with an alternative means of dispute resolution because court proceedings are generally too slow, too costly and too complicated for small consumer claims. So practically, the inferior proposed solution may be the consumer's only practicable option. ${ }^{15}$ By allowing Member States to provide only for ADR bodies that propose solutions which do not necessarily need to meet the requirements of material consumer law, the EU seems to facilitate the creation of what has been called the distinction between the law in the books and the law in action. ${ }^{16}$ Based on the

\footnotetext{
11 Art. 11 ADR Directive.

12 Cf. Wagner, 178; Weber, 281.

13 Cf. Wagner, 177.

14 See Art. 9(2) ADR Directive.

15 Cf. Rühl (SSRN) 17.

16 Roscoe Pound, 'Law in the Books and Law in Action', (1910) 44 American LR 15.
} 
harmonized rules of material consumer law, consumers in the EU have certain minimum rights, but in practice they may have to accept an inferior solution.

One could argue the following: without an ADR body that proposes a solution, the consumer who has low value claims does not obtain any remedy at all. Compared to this, an ADR body proposing a solution means progress, even if that solution does not deliver exactly what the consumer is entitled to under hard core law. I agree that ADR bodies which are not bound to apply the law may, in the short term, result in benefits for consumers compared to the current situation where court proceedings are not suited to deal with low value consumer claims. However, I am afraid that in the long run the disadvantages for the internal market will outweigh these benefits. These disadvantages result from an uneven level playing field for traders, legal uncertainty for cross-border consumer transactions and the creation of a law in action that differs from the law in the books, created by the material rules of consumer law. Would both the consumers' and the EU's interests not be better served with amendments to the national courts' systems in order to make it better suited to deal with consumer cases? ${ }^{17}$

This is all the more the case since the risk contained in the ADR Directive for the creation of a separate body of law in action that differs from the law in the books is only the most obvious in cases where the ADR body is only able to propose solutions instead of imposing them. As mentioned above, even with regard to ADR bodies that impose solutions, the ADR Directive only ensures that the consumer does not get less than he is entitled to under the mandatory rules according to the applicable law. The Directive does not guarantee the application of contractual rules that are more beneficial to the consumer, or by contrast, the application of standards of consumer protection that are more consumer friendly than the rules contained in Consumer Rights Directives based on maximum harmonisation.

The ADR Directive also seems to fall short in offering the normal guarantees for the proper administration of justice. ${ }^{18}$ Although the Directive purports to offer guarantees relating to the expertise of the members of the ADR bodies, their

17 Cf. also Eidenmüller and Engel, 2014, 261-298.

18 Cf. Eidenmüller and Engel, 2014, 288-294. 
independence and impartiality, the value of these guarantees is questionable. The natural persons in charge of ADR do not need a university degree in law. It is sufficient that they "possess the necessary knowledge and skills in the field of alternative or judicial resolution of consumer disputes, as well as a general understanding of law". ${ }^{19}$

Although the Directive provides a list of requirements in order to guarantee the independence and impartiality of the natural persons in charge of $\mathrm{ADR}^{20}$, it is not opposed against them being "employed or remunerated exclusively by a professional organisation or a business association of which the trader is a member", provided they have "a separate and dedicated budget at their disposal which is sufficient to fulfil their tasks"21. Provided that the additional requirements of Article 6(3) ADR Directive $^{22}$ are complied with, Member States may even consider procedures before dispute resolution entities as ADR procedures where the natural persons in charge of dispute resolution are employed or remunerated exclusively by the individual trader. $^{23}$

Similarly, the ADR Directive purports to ensure transparency, requiring ADR entities to make clear and understandable information on a whole list of elements (for example their contact details, the natural persons in charge of ADR, the method of their appointment and the length of their mandate) publicly available on their websites as well as on a durable medium upon request, and by any other means they consider appropriate ${ }^{24}$. However, the ADR Directive does not require the decisions of the ADR bodies to be published. ${ }^{25}$ There is only a duty to make public annual reports

\footnotetext{
${ }^{19}$ Art .6(1)(a) ADR Directive. Critical on this point also Eidenmüller and Engel, 2013, 1707;

Eidenmüller and Engel, 2014, 288; C. Meller-Hannich, A. Höland \& E. Krausbeck, 36-37.

${ }^{20}$ Art. 6 ADR Directive. It is required, for example, that the natural persons are appointed for a term of office of sufficient duration to ensure the independence of their actions, and are not liable to be relieved from their duties without just cause; that they are not subject to any instructions from either party or their representatives; that they are remunerated in a way that is not linked to the outcome of the procedure.

${ }^{21}$ Art. 6(4) ADR Directive. Critical also Wagner, 174.

22 E.g. that the natural persons in charge of dispute resolution are nominated by, or form part of, a collegial body composed of an equal number of representatives of consumer organisations and of representatives of the traders and are appointed as result of a transparent procedure.

${ }^{23}$ Art. 2(2)(a) ADR Directive. Critical also C. Meller-Hannich, A. Höland \& E. Krausbeck, 37;

Wagner, 174; Weber, 280-281.

${ }^{24}$ Art. 7(1) ADR Directive.

${ }^{25}$ Cf. Rühl (SSRN) 17.
} 
containing generalised information on, for example, the number of disputes received and the types of complaints to which they related; the percentage share of ADR procedures which were discontinued and, if known, the reasons for their discontinuation; the average time taken to resolve disputes, as well as any systematic or significant problems that occur frequently and lead to disputes between consumers and traders; such information may be accompanied by recommendations as to how such problems can be avoided or resolved in future, in order to raise traders' standards and to facilitate the exchange of information and best practices ${ }^{26}$. In the absence of the publication of the individual decisions, however, this does not seem sufficient to guarantee the transparency of their decisions, or the predictability of the outcomes of cases brought before them.

\section{Conclusion}

To conclude, the ADR Directive pursues an honourable aim, trying to provide consumers and traders with access to a simple, fast and low-cost method of dispute resolution. In the short term, it will probably improve the position of consumers compared to the status quo ante. However, it does not guarantee consumers the remedy they are entitled to. It institutionalises a system that does not meet the standards for the proper administration of justice and it may jeopardise the efforts made for the harmonization of the material rules of consumer protection and the creation of a level playing field for traders in the internal market in the long term. An EU measure aimed at amending the existing court procedures in the Member States in order to make them better suited to deal with low value consumer claims would have been preferable.

${ }^{26}$ Art. 7(2) ADR Directive. 